\title{
Изучение процентного содержания фосфора в коллекции картофеля вида Solanum tuberosum
}

\author{
И.В. Розанова ${ }^{1 *}$, В.К. Хлесткин ${ }^{1}$, В.М. Ефимов ${ }^{1}$, Е.К. Хлесткина ${ }^{1,2}$ \\ ${ }^{1}$ ФИЦ Институт иитологии и генетики СО РАН, Новосибирск, Россия \\ ${ }^{2}$ ФИЦ Всероссийский институт генетических ресурсов растений имени Н.И. Вавилова (ВИР), \\ Санкт-Петербург, Россия \\ *e-mail: bykova@bionet.nsc.ru
}

Цель: Картофель занимает четвертое место по потреблению и производству среди продовольственных культур. Содержание фосфора в сельскохозяйственной культуре, в том числе и в картофеле, является важным пищевым и кормовым параметром, которое необходимо учитывать при разработке сортов. Использование ДНК-маркеров, ассоциированных с целевым признаком получаемых в ходе GWAS анализа, позволяет сократить время селекционных работ. Целью настоящей работы является определение локусов, ассоциированных с содержанием фосфора в коллекции картофеля вида Solanum tuberosum.

Pезультаты: Была создана выборка, состоящая из 96 сортов S. tuberosum. Bce 96 сортов были проанализированы на содержание фосфора. Среднее содержание фосфора в образцах по выборке составило 0,072%. Минимальное содержание было отмечено для сорта «Дебрянский» и составило 0,046 \%, максимальное для сорта «Ладожский» и составило 0,104 \%. Для данных сортов было проведено генотипирование на чипе Illumina Infinium с 22 тысячами маркеров. Из 21226 SNP, для полногеномного анализа ассоциаций были использованы 15214 маркеров. Данные обрабатывались с помощью программ Microsoft Excel, Tassel 5, пакета R, Rast и Statistica. Анализ данных с помощью GLM модели позволил выявить 5 SNP, которые значимо ассоциировались с содержанием фосфора в образцах на 1Н хромосоме.

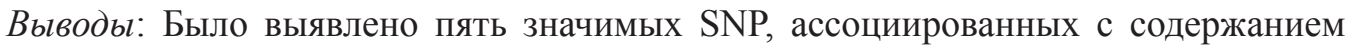
фосфора в образцах сортов Solanum tuberosum, расположенных на хромосомах $1 \mathrm{H}$. Благодарности: Работа выполнена при поддержке РФФИ, № 17-29-08006. 